\title{
Factors Affecting Residents' Support for Protected Area Designation
}

\author{
Sunjoo Park ${ }^{1}$, Seweryn Zielinski ${ }^{2, *} \mathbb{C}$, Yoonjeong Jeong ${ }^{1}$ and Seong-il Kim ${ }^{1,3}$ (i) \\ 1 Department of Forest Sciences, Seoul National University, 1 Gwanak-ro, Gwanak-gu, Seoul 08826, Korea; \\ sjpark78@snu.ac.kr (S.P.); yoonjeong522@snu.ac.kr (Y.J.); seongil@snu.ac.kr (S.-i.K.) \\ 2 Department of Hospitality and Tourism Management, Sejong University, 209 Neungdong-ro, Gwangjin-gu, \\ Seoul 05006, Korea \\ 3 Research Institute of Agriculture and Life Sciences, Seoul National University, 1 Gwanak-ro, Gwanak-gu, \\ Seoul 08826, Korea \\ * Correspondence: zielinski@sejong.ac.kr; Tel.: +82-2-3408-3807
}

Received: 23 January 2020; Accepted: 31 March 2020; Published: 1 April 2020

check for updates

\begin{abstract}
This study examined the formation of residents' behavioral intentions to support the expansion of protected areas (PAs). A structural equation model combining the theory of planned behavior and an expectancy disconfirmation model were employed to test seven hypotheses on the influence of expectations, performance, satisfaction, attitudes, subjective norms, and perceived behavioral control on behavioral intention to support PA designation. The findings indicate that although the expectations of PA performance did not significantly influence the satisfaction from PAs, the perceived performance after the designation significantly contributed to building satisfaction, which in turn had a significant role in explaining attitudes. Furthermore, positive and significant associations of subjective norms and behavioral control with behavioral intention to support additional designation were identified. These results provide indications for PA managers and environmental agencies regarding aspects to consider when engaging in planning with local communities and appropriate ways to respond to their concerns.
\end{abstract}

Keywords: expectancy disconfirmation; planned behavior; Baekdudaegan; community; structural equation; protected area

\section{Introduction}

Protected areas (PAs) have been widely used as one of the central strategies for biodiversity conservation around the world [1]. PAs comprise areas that often integrate a wide range of land uses. Therefore, their designation by national governments requires not only political support but also local support from communities inhabiting the area, which is perhaps more important. Because the zonation or other imposed restrictions may conflict with local property rights, commercial interests, or local people's perceptions toward different issues in the region [2,3], residents may be forced to bear losses associated with these areas and perceive them as a threat to their livelihoods [4].

The importance of local participation in planning and management has been emphasized in the context of PAs [5,6]. It is believed to have potential to transform the attitudes of the local people from passivity to responsibility, creating a sense of purpose and ownership [7]. Successful environmental protection can be enhanced if protection goals are shared and supported by the local population [8]. Hence, participatory planning approaches applied through stakeholder surveys, and mechanisms to involve communities in managing, coordinating, and integrating their internal programs and activities have been widely promoted [9]. A study carried out on 90 PAs in 42 countries identified participation to be the most important factor influencing their success or failure [10]. The rationale 
for the involvement of the local people is centered in their historical understanding of the area and the way it adapts to change, and the fact that the local people will be affected by the declaration of a PA [11]. For conservation programs to succeed, managers must understand the role of a PA in the lives of the local people, rather than vice versa [12]. As residents often feel their livelihoods will be impacted and they will bear the costs of conservation [4,13], decisions without their consent will likely generate resistance and potentially conflict in the long-term. Hence, in the planning and management of modern PAs, increasing attention is being paid to social support, which makes behavioral studies a key tool to evaluate public attitudes toward and acceptance of conservation initiatives [14].

The objective of this study was to provide a better understanding of the factors that affect residents' support for the establishment or expansion of PAs by examining the formation of residents' behavioral intentions to support the expansion of PAs. A structural equation model combining the theory of planned behavior and expectancy disconfirmation model was employed to test seven hypotheses on the influence of expectations, performance, satisfaction, attitudes, subjective norms, and perceived behavioral control on behavioral intention to support PA designation. Although there is a myriad of studies on residents' attitudes toward conservation and PAs, very few studies empirically examined how these attitudes are created and whether there are other factors that lead to the actual behavior to support PAs. Hence, the contribution of the paper is centered on answering those questions that consist of important information for policymakers and stakeholders regarding the designation, management, and expansion of protected areas, which are crucial for sustainable development. The findings and suggested approaches would help policymakers and decision-makers develop more effective and transparent strategies with an equal participation of local communities to generate positive attitudes among them.

\subsection{Literature Review}

\subsubsection{Expectancy Disconfirmation Model}

Satisfaction has been acknowledged as one of the most meaningful predictors of behavioral intentions [15]. To study consumer behavior and explain cognitive mechanisms used to achieve satisfaction, Oliver $[16,17]$ developed the expectancy disconfirmation model (EDM). The model suggests that satisfaction is a function of the differences between consumers' expectations and perceived results (performance). In the context of PAs, the performance of an area in terms of services and benefits provided to the residents does not translate to satisfaction if the initial expectations of that performance surpass the actual performance [16]. In other words, individuals tend to be satisfied with PAs when their perceived performance exceeds their expectations and dissatisfied when their perceived performance falls short of expectations [18]. The perceived negative and positive outcomes of a consumer experience are called negative and positive disconfirmation, respectively [17]. Hence, satisfaction is not a consequence of the actual performance alone, but also residents' expectations about what a PA should offer them as shaped by information gathered through many sources and personal experience with PAs and the corresponding administrators [19].

The applicability of EDM has been confirmed by numerous studies, primarily those dealing with consumer satisfaction from products and services. However, only few studies have applied EDM in the context of PAs or parks to explain visitors' satisfaction from products and services [20,21]. To the best of the authors' knowledge, the satisfaction of residents from PAs has not been explored using the model. Perhaps citizen satisfaction with government performance [22-26] has been the most relevant area of research thus far, especially considering studies that have investigated a broad range of local or urban services $[20,27,28]$. In general, the results of such studies have been consistent, demonstrating a direct positive causal relationship between positive disconfirmation and satisfaction, and satisfaction and behavioral intention. This is congruent with a considerable amount of empirical evidence from different fields [29-31]. Furthermore, the literature supports the fact that satisfaction is also directly 
influenced by expectation and performance. Expectations directly and negatively affect satisfaction, whereas performance directly and positively affects satisfaction $[16,17,32]$.

Relevant to the discussion are findings of studies that explored the reasons for residents perceiving low or high performance of PAs and deciding whether to support them. Two major themes have been repeatedly identified to play a central role in residents' support: (1) potential of PAs to deliver associated benefits for the local population that outweigh the costs [8,33,34]; and (2) recognition of such benefits by the local people $[8,13]$. As the designation of a PA implies some restrictions to local residents, they must feel that the benefits outweigh the cost that they will bear as a direct result of PA establishment [35]. Such a perception of costs and benefits depends on the scale of benefits in relation to residents' dependence on local resources, and their knowledge of the PA [36,37] and its potential to provide mostly tangible benefits [4]. As the local people are highly dependent on resources, they are more likely to support only "conditioned conservation", which recognizes the value of biodiversity not only as aesthetic, ethical, or ecological, but also as a means to improve the quality of life of the local people [13].

\subsubsection{Theory of Planned Behavior}

The theory of planned behavior (TPB) is now the most extensively used social-psychological model [38]. It is particularly well suited to explain environmental behavioral intentions [39]. This theoretical model originated from the field of social psychology, and it is based on the concepts of beliefs, attitudes, norms, perceptions, and behavior [40]. TPB provides a sound foundation for predicting behavioral intentions by measuring the underlying determinants of the associated behavior: attitudes, subjective norm, and perceived behavioral control [41].

An attitude towards a behavior can be a positive or negative evaluation of the performance of the behavior [40]. Subjective norm is the person's perception of what others think of a particular behavior [40,42]. It is a function of normative beliefs and the motivation to comply with what a person considered to be important or influential (e.g., village elder, family member, group leader) thinks is appropriate behavior [43]. For example, according to TPB, a person would be more likely to support a PA if he or she believes that his or her family or leaders would also support it, although such a perception may not reflect what others actually think. Perceived behavioral control (PBC) recognizes that one's positive attitudes do not necessarily lead to action [40,42]. It is a measure of the perceptions of their abilities to perform a given behavior [44]. PBC explains that a person's positive attitudes and intentions can be effectively hindered by psychological barriers that may be formed by the perceived absence of skills, knowledge, autonomy, or material items required to perform a behavior [43]. All three constructs combined explain the behavioral intention, which is the closest determinant of the actual behavior [40].

The model has been widely accepted in social sciences and validated by many studies in various contexts (see [44-46]). Its application to PAs has been centered primarily on explaining the pro-environmental behavior of visitors (e.g., [47]). Very few studies applied the model or its parts to investigate local residents' conservation behavior and support for PAs. St John et al. [43] carried out a review study on conservation behavior and found that attitude alone is an unreliable predictor for behavior, and theories of planned behavior and reasoned actions are more appropriate. Infield and Namara [48] concluded that attitudes towards a park and a wildlife conservation program were significantly more positive in communities that benefited from development assistance than in those who did not. They also found that the attitudes and behavior of the communities did not improve even after seven years of the program. Dolisca et al. [49] found that attitudes toward the environment and perceived behavioral control significantly influenced forest conservation behavior, whereas the influence of subjective norms was insignificant. They concluded that conservation behavior was greatly influenced by organizational, structural, and environmental characteristics of the villages. Ward et al. [50] explored perceived barriers (cost and benefits) to and drivers of community participation in PA governance in Madagascar. Their results suggest that focusing on attitudes could encourage 
participation, as it was found to be limited by perceived high costs attributed to miscommunication and lack of knowledge about the benefits. Finally, Castilho et al. [51] addressed local residents' practices of hunting and deforestation in three PAs and their buffer zones in the Southern Bahian Atlantic Forest (Brazil). They found that a combination of demographic factors, values held for protected areas, and location influenced the attitudes, descriptive norms, and perceived behavioral control of respondents. In all these cases the TPB proved to be effective in explaining the behavior of the local people.

\subsection{Proposed Conceptual Model and Hypotheses}

Model specifications define the hypothesized relationships among the variables in a structural equation model (SEM) based on one's knowledge. In this study, two well-known and researched models were merged to create a more robust model that can explain the factors that influence attitudes. Yoon [52] explained local residents' support for festivals using a theoretical model merging EDM and constructs from TPB. This model removed disconfirmation to validate the direct effects of expectations and performance on satisfaction based on previous studies, because the results of the relationships of expectations, performance, and disconfirmation were not consistent $[32,53,54]$ Adopting the revised Yoon's [52] model, this study included the following constructs: (1) residents' expectations of PA performance; (2) perceptions of the actual performance; (3) Satisfaction; (4) Attitudes; (5) Subjective norm; (6) Perceived behavioral control; and (7) Behavioral intention (Figure 1). EDM was added to encompass factors suitable for explaining attitudes because attitude information alone is limited in terms of the predictors of pro-conservation behaviors [43].

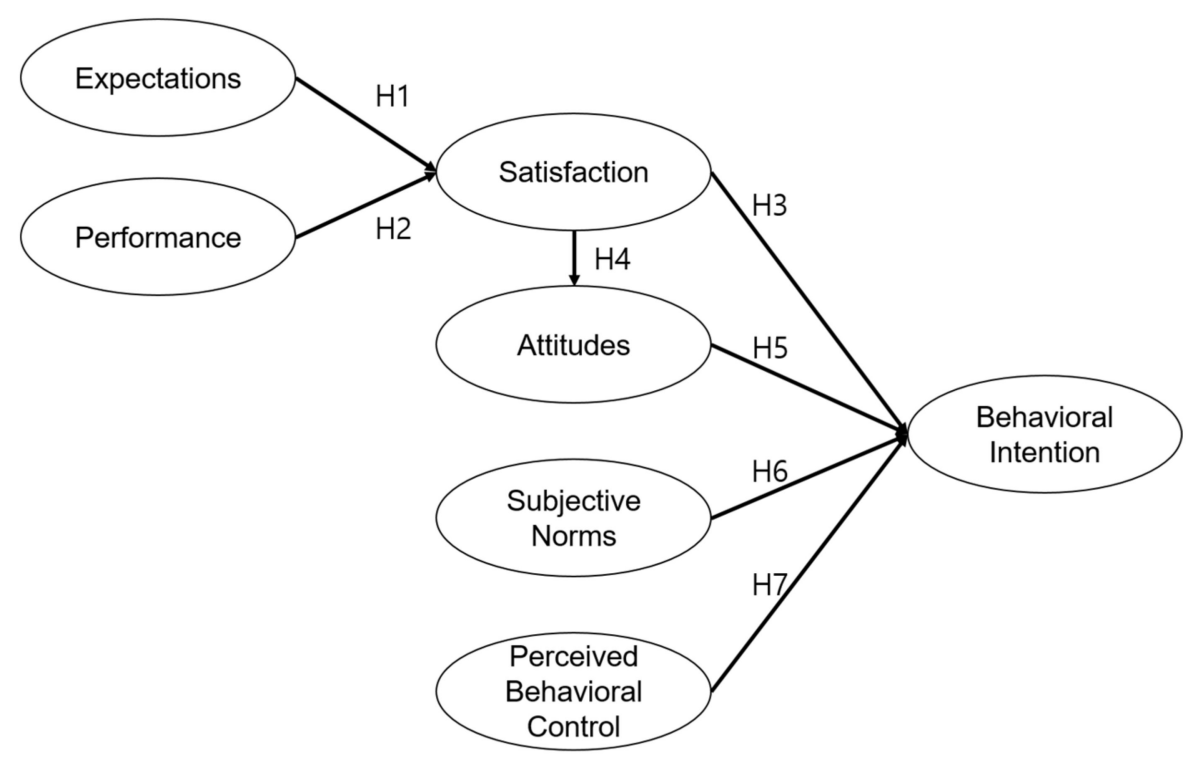

Figure 1. The conceptual model.

Based on previous literature, seven hypotheses were proposed. The first three (H1, H2, H3) were adopted from the expectancy disconfirmation model (EDM) [16,17] that has been previously validated in many studies [20-22,27-31]. In general, the results of those studies have been consistent, demonstrating a direct positive causal relationship between positive disconfirmation and satisfaction [22,27-31], and satisfaction and behavioral intention (e.g., [20,21]). Furthermore, the literature supports the fact that satisfaction is also directly influenced by expectation and performance. Expectations directly and negatively affect satisfaction, whereas performance directly and positively affects satisfaction $[16,17,21,32]$. Because previous studies confirmed the abovementioned relationship between satisfaction and behavioral intention $(\mathrm{H} 3)$, this study sought to test that hypothesis and additionally hypothesized that attitudes can mediate those two constructs (H4) as it was supported 
by studies that confirmed residents' satisfaction from performance of PAs (in terms of costs and benefits) being the main factor that affects their attitudes towards supporting PAs (e.g., [43,47-51]). It was also in line with the theory of reasoned action. Finally, hypotheses H5, H6, and H7 were adopted directly from the theory of planned behavior, which is particularly useful in explaining environmental behavioral intentions [39]. The three constructs of the model were used to form the three hypotheses that have been widely accepted in social sciences and validated by many studies in various contexts (see [44-47]), including conservation behavior and support for PAs [43,48,51].

Hypothesis 1 (H1): Expectations of the performance of PAs before designation will affect the residents' satisfaction from the PAs.

Hypothesis 2 (H2): The perceived performance of PAs will affect the residents' satisfaction from the PAs.

Hypothesis 3 (H3): The residents' satisfaction from PAs will affect their behavioral intention to support the expansion of the PAs (additional designation).

Hypothesis 4 (H4): The residents' satisfaction from PAs will affect their attitudes towards supporting additional designation.

Hypothesis 5 (H5): The residents' attitudes towards supporting expansion of PAs will affect their behavioral intention to support additional designation.

Hypothesis 6 (H6): The residents' subjective norms towards supporting expansion of PAs will affect their behavioral intention to support additional designation.

Hypothesis 7 (H7): The residents' perceived behavioral controls of supporting expansion of PAs will affect their behavioral intention to support additional designation.

\section{Materials and Methods}

\subsection{Study Area}

Baekdudaegan is a mountain range that crosses the entire Korean Peninsula from Mt. Baekdu on the border between North Korea and China to Mt. Jiri in South Korea. It consists of Mt. Baekdu (2750 m), Mt. Kumgang (1639 m), Mt. Odae (1563 m), and Mt. Jiri (1915 m). Baekdudaegan plays an important role as a key ecological axis of the Korean Peninsula that hosts a wide range of species [55]. Furthermore, Baekdudaegan has been regarded as an important symbol by Koreans as it holds various cultural assets. In order to protect this area, the "Baekdudaegan Protection Act" was enacted in 2003, according to which 263,427 ha were designated as the core or a buffer zone. Baekdudaegan contains 11 different kinds of PAs that are managed by three governmental agencies through six different acts. Despite the protection status, more than 80 specific zones are in danger of being damaged by the increasing intensity of tourism and leisure activities as well as by the expansion of agriculture [55].

Villages near the PAs are inhabited by rural communities characterized by relatively low income and education level. The study area encompasses a large part of Namwon's Baekdudaegan Protected Area (BDPA). According to the available data in 2005, this area covers approximately 1600 households in 42 villages across the administrative area of $19,095 \mathrm{ha}, 89.5 \%$ (17,082 ha) of which is under one of the three levels of protection (5858 ha core zone; 1482 ha buffer zone; and 9742 ha transition zone). More than half of the inhabitants were in their 60s in 2005, and there was a strong migration from the rural area to larger cities [56]. Therefore, the actual population was believed to be much lower at the time of data collection, which was 11 years later. However, no official data were available to illustrate the scale of depopulation. According to an unofficial survey carried out in 2014, the number of households in Namwon's BDPA was 414 [57]. 
Government agencies view PAs as an opportunity to generate income for rural people and conserve the natural environment. Meanwhile, the Korea Forest Service (KFS) and related ministries have been carrying out projects to support the villages by providing infrastructure and opportunities to increase income. Accordingly, forest product storage facilities, processing plants, and community centers for senior residents were built, together with hiking trails along the Baekdudaegan ridge to increase the number of visitors to the villages. The KFS advertised the designation as a mechanism for promoting the region and promised to support eco-tourism development [55]. However, the designation of the original PA introduced development restrictions that led to conflicts. The local residents recognized the new policy as another type of regulation designed to limit their freedom of development. At briefing sessions for potential biosphere conservation areas held in early 2015, many residents of the Namwon area expressed strong opposition to the additional designation of PAs, distrusting new government policies [55].

\subsection{Structural Equation Model}

Structural equation modeling (SEM) is a powerful, multivariate technique found increasingly in scientific investigations to test and evaluate multivariate causal relationships. SEMs differ from other modeling approaches as they test the direct and indirect effects on pre-assumed causal relationships. A common function of path analysis is mediation, which assumes that a variable can influence an outcome directly and indirectly through another variable. Because this study merged two theories, satisfaction was both a dependent variable and an explanatory variable in the model. SEM has the advantage of estimating this kind of interdependent relationship of multiple variables reflecting errors of measurement.

\subsection{Measurement Items}

The measurement items for residents' behavioral intention to support the expansion of PAs were adapted from a range of studies that used EDM and TPB. In particular, four items for expectations and four items for performance, as well as seven items for satisfactions [58-60], and three items for attitudes, subjective norms, and perceived behavior control $[57,60,61]$ were adopted. Behavioral intention to support the expansion of PAs was measured with one item adapted from Ajzen [42] and Yoon [52]. The first group of the items measured expectations of residents to receive economic, cultural, and environmental benefits from PAs before the designation. The second set of items measured performance of the protected area in terms of perceived effectiveness in delivering those benefits after the designation. Satisfaction was evaluated through seven items that measured (1) overall satisfaction, (2) economic satisfaction, (3) cultural satisfaction (senior center, cultural center, accommodations, and restaurants), (4) environmental satisfaction (environmental benefits), (5) expectancy confirmation in terms of meeting expectations, (6) satisfaction from received information about the designation process, and (7) awareness of the existence of the PAs. Attitudes were measured in terms of positive or negative perception of designation and favoritism towards it. Subjective norms were measured through items relating to the respondents' families', friends' and neighbors' agreement for designation of PAs, the respondents' declaration to follow their opinion, and their perception of respondents' agreement to the expansion of the PAs. Perceived behavior control was measured through items related to the respondents' ability to participate in public hearing or briefing sessions for the expansion of protected areas, their availability of time to participate, and their declaration of following the process. Finally, behavioral intention was measured through the declaration of support for the expansion of protected areas (additional designation). It was measured using a single item because it was a dichotomous question and previous literatures used this kind of method to deal with categorical responses demonstrating its reliability and validity $[62,63]$. A complete list of measurement variables is shown in the Appendix A.

In addition, respondents were asked questions about the reasons for their dissatisfaction with the current PAs. The questionnaire was developed based on [64], and it included the following causes of 
dissatisfaction: (1) increased damage caused by wild animals; (2) restrictions on development of the area; (3) lack of projects for community business development; (4) infringement of property rights; (5) restrictions on community participation; and (6) increased number of visitors. Lastly, based on the results of a single pre-test with academics and two subsequent pre-tests with local residents for face validity, two items with low factor loadings on attitude and perceived behavioral control were deleted.

\subsection{Data Collection and Analysis}

Local residents of the villages in BDPA in Namwon area, Jeon-ra Province, were surveyed on the 27 and 28 of August and between 7 and 11 of October 2015 using a stratified sampling method. Because each village tends to have its own community sentiment and opinion, the sample was stratified by townships as sub-populations. First, a list of villages in each township was created. Subsequently, the villages for data collection were determined proportionally within the townships. Because the population size was inaccurate as mentioned above, the sample size was determined as $10 \%(120)$ of the total households in each village through consultation with the leader of each village. Increasing the sample size was not possible. In total, 15 villages were surveyed. Only one member of a household was allowed to participate in the survey. A group of trained assistants helped the interviewees complete the questionnaire. A total of 102 valid questionnaires were obtained out of 121 distributed, which given the total estimated population of 414 households [56], gave a confidence interval of $8.5 \%$ at the confidence level of $95 \%$.

AMOS 26 and SPSS 18 were used to analyze data. Reliability analysis (Cronbach's alpha) was performed to confirm the internal consistency of the items. Confirmatory factor analysis was then used to verify the convergent and discriminant validity of the factors. Subsequently, path analysis was conducted to evaluate the hypothesized research framework.

\section{Results}

\subsection{Sample Characteristics}

Among the 102 respondents who completed the questionnaire, $67.4 \%$ were male and $32.6 \%$ were female. Most respondents were over 60 years old (66.6\%). In terms of education, $61.8 \%$ of the respondents had only basic pre-high school education, $29.9 \%$ were high school graduates, and $9 \%$ had bachelor's degrees. A total of $47.5 \%$ of respondents earned less than 1,000,000 KRW (850 USD) per month, 27.5\% earned between 1,000,000 KRW and 2,000,000 KRW (850-1700 USD) per month, and $27.5 \%$ earned more than 2,000,000 KRW (1700 USD). Regarding occupation, most respondents were farmers $(83.5 \%)$ and $10.3 \%$ were homestay hosts or self-employees. These characteristics correspond to results of previous studies, in which $41 \%$ of residents were over 60 years old in 2005, 57\% were males, $10 \%$ had a bachelor's degree (average), and $85 \%$ were farmers [55,56].

\subsection{Causes of Dissatisfaction from PAs}

Regarding the causes of dissatisfaction from the current PAs and lack of support for further designation, "increased damage caused by wild animals" was the most frequently reported reason (68 respondents) followed by "restrictions on development of the area" (52 respondents), "lack of projects for community business development" (52 respondents), "infringement of property rights" (36 respondents), "restrictions on community participation" (36 respondents), and "increased number of visitors" (35 respondents).

\subsection{Measurement Model}

Cronbach's alpha values lower than Hair et al.'s [65] recommended cutoff of 0.600 were eliminated in order to ensure the internal consistency of the items. Six of the twenty-four items were eliminated through this process (Table 1). Factor loadings, average variance extracted (AVE), and construction reliability (CR) were calculated to verify the convergent validity (Table 2). All of the AVE values 
exceeded 0.500 , and CR values were between 0.866 and 0.945 , higher than 0.700 , which supported convergent validity $[65,66]$. The AVE values were also greater than the between-variable correlations (Table 3), which supported the discriminant validity [66,67].

Table 1. Internal consistency of variables.

\begin{tabular}{ccc}
\hline Variables & Item & Cronbach's $\alpha$ \\
\hline Expectations & 4 & 0.911 \\
Performance & 3 & 0.869 \\
Satisfaction & 5 & 0.886 \\
Attitude & 2 & 0.872 \\
Subjective norms & 2 & 0.698 \\
Perceived behavioral control & 2 & 0.882 \\
\hline
\end{tabular}

Table 2. Results of AVE and factor analysis.

\begin{tabular}{ccccccc}
\hline $\begin{array}{c}\text { Var. } \\
\text { (AVE) }\end{array}$ & $\begin{array}{c}\text { Expectations } \\
\mathbf{( 0 . 7 8 8 )}\end{array}$ & $\begin{array}{c}\text { Performance } \\
\mathbf{( 0 . 8 0 9 )}\end{array}$ & $\begin{array}{c}\text { Satisfaction } \\
\mathbf{( 0 . 7 2 2 )}\end{array}$ & $\begin{array}{c}\text { Attitudes } \\
\mathbf{( 0 . 8 8 9 )}\end{array}$ & $\begin{array}{c}\text { SN } \\
\mathbf{( 0 . 7 6 4 )}\end{array}$ & $\begin{array}{c}\text { PBC } \\
\mathbf{( 0 . 8 9 5 )}\end{array}$ \\
\hline E1 & 0.833 & 0.174 & 0.213 & 0.240 & 0.267 & 0.223 \\
E2 & 0.904 & 0.300 & 0.281 & 0.228 & 0.299 & 0.336 \\
E3 & 0.891 & 0.3501 & 0.302 & 0.305 & 0.322 & 0.295 \\
E4 & 0.919 & 0.261 & 0.296 & 0.320 & 0.323 & 0.385 \\
P1 & 0.372 & 0.954 & 0.673 & 0.577 & 0.478 & 0.314 \\
P2 & 0.227 & 0.906 & 0.637 & 0.525 & 0.418 & 0.356 \\
P3 & 0.227 & 0.835 & 0.484 & 0.423 & 0.268 & 0.234 \\
S1 & 0.278 & 0.635 & 0.907 & 0.700 & 0.607 & 0.500 \\
S2 & 0.193 & 0.614 & 0.908 & 0.634 & 0.495 & 0.492 \\
S3 & 0.243 & 0.586 & 0.853 & 0.612 & 0.458 & 0.457 \\
S4 & 0.258 & 0.520 & 0.828 & 0.565 & 0.569 & 0.429 \\
S5 & 0.361 & 0.495 & 0.739 & 0.518 & 0.399 & 0.345 \\
A1 & 0.242 & 0.529 & 0.659 & 0.939 & 0.628 & 0.494 \\
A3 & 0.340 & 0.550 & 0.692 & 0.948 & 0.667 & 0.507 \\
SN1 & 0.350 & 0.455 & 0.580 & 0.699 & 0.917 & 0.577 \\
SN2 & 0.234 & 0.300 & 0.455 & 0.473 & 0.828 & 0.427 \\
PBC1 & 0.312 & 0.313 & 0.523 & 0.515 & 0.605 & 0.949 \\
PBC3 & 0.360 & 0.329 & 0.472 & 0.489 & 0.498 & 0.943 \\
\hline
\end{tabular}

SN - Subjective norms; PBC - Perceived behavioral control.

Table 3. AVE and correlations with variables.

\begin{tabular}{ccccccc}
\hline & Expectations & Performance & Satisfaction & Attitudes & SN & PBC \\
\hline Expectations & $(0.788)$ & & & & & \\
Performance & 0.097 & $(0.809)$ & & & & \\
Satisfaction & 0.097 & 0.454 & $(0.722)$ & & & \\
Attitudes & 0.096 & 0.327 & 0.514 & $(0.889)$ & & \\
SN & 0.118 & 0.197 & 0.359 & 0.473 & $(0.764)$ & $(0.895)$ \\
PBC & 0.126 & 0.115 & 0.278 & 0.282 & 0.342 & $(0.278)$ \\
\hline
\end{tabular}

\subsection{Structural Model Assessment}

The results of the model assessment showed a satisfactory fit to the data (Table 4). Model convergence is the degree of agreement between a study model and the model using the actual covariance data, which can be considered a correspondence between the characteristics of the sample and the theoretical characteristics [68]. Although the model fit is usually determined by a chi-square test value, several other indices have been used for the assessment. Studies have suggested that it is generally desirable to consider CFI (comparative fit index), TLI (Tucker-Lewis index), and RMSEA (root mean square error of approximation) values together to judge the model 
fit $[68,69]$. It was determined that 2/df was less than 2 and that the CFI, TLI, and RMSEA values complied with the recommended thresholds.

Table 4. Model fit.

\begin{tabular}{ccc}
\hline Index & Recommended & Measured Value \\
\hline CMIN & chi-square & 187.424 \\
$\mathrm{p}$ & $>0.005$ & 0.000 \\
CMIN/df & $1-3$ & 1.752 \\
RMSEA & $<0.10$ & 0.086 \\
GFI & $\geq 0.9$ & 0.826 \\
NFI & $\geq 0.9$ & 0.867 \\
CFI & $\geq 0.9$ & 0.937 \\
IFI & $\geq 0.9$ & 0.938 \\
TLI & $\geq 0.9$ & 0.919 \\
\hline \multicolumn{2}{c}{ Sources of recommended values: $[60-62]}$.
\end{tabular}

The critical ratio (CR) that verifies the estimate of the model can be considered the same as the $t$ value for ANOVA. That is, if the CR value is greater than \pm 1.96 , the coefficient is significant at the $5 \%$ significance level. Estimates of the path analysis of the model are given in Table 5 . The analysis shows that performance affects satisfaction, and satisfaction significantly affects attitudes. The factors that affected the residents' support for additional PA designation were perceived behavioral control, attitudes, and subjective norms.

Table 5. Significance test of the regression model (non-standardized regression value).

\begin{tabular}{cccccccc}
\hline H & \multicolumn{2}{c}{ Proposed Paths } & Estimate & SE & CR & $p$ \\
\hline H1 & Satisfaction & $\leftarrow$ & Expectations & 0.044 & 0.066 & 0.666 & 0.505 \\
H2 & Satisfaction & $\leftarrow$ & Performance & 0.765 & 0.103 & 7.457 & $* * *$ \\
H3 & Behavioral intention & $\leftarrow$ & Satisfaction & 0.122 & 0.129 & 0.817 & 0.414 \\
H4 & Attitudes & $\leftarrow$ & Satisfaction & 0.712 & 0.103 & 7.561 & $* * *$ \\
H5 & Behavioral intention & $\leftarrow$ & Attitudes & 0.383 & 0.129 & 2.967 & 0.003 \\
H6 & Behavioral intention & $\leftarrow$ & SN & 0.303 & 0.097 & 3.137 & 0.002 \\
H7 & Behavioral intention & $\leftarrow$ & PBC & 0.565 & 0.097 & 5.851 & $* * *$ \\
\hline
\end{tabular}

*** $p<0.001$; SE-Standard Error; CR-Critical Ratio.

There was no significant correlation among variables in this model. Low correlation between expectations and performance $(=0.312, p=0.0004)$ was found, but modification of the model was not necessary for this value [68].

Finally, the proposed relationships among the constructs were tested. Path analysis using AMOS software confirmed five of the seven hypotheses at a 95\% confidence level. The results show that expectations about performance before the designation of PAs did not affect the satisfaction level after the designation (H1 rejected). However, the performance of PAs after the designation had a positive and significant impact on the satisfaction level from PAs (H2 accepted). Moreover, although the results show that satisfaction from the performance of PAs did not directly affect the residents' behavioral intention to support additional designation (H3 rejected), it affected the attitudes toward additional designation (H4 accepted), which in turn showed significant and positive relationships with behavioral intention to support additional designation (H5 accepted). Furthermore, the results demonstrate the positive and significant association of subjective norms with behavioral intention (H6 accepted) and behavioral control with behavioral intention to support additional designation (H7 accepted).

The explanatory power of each factor is represented as an $R^{2}$ value. The $R^{2}$ value of satisfaction $(=0.529)$ shows that performance explained $52.9 \%$ of the variance in satisfaction (Figure 2). Generally, if the $\mathrm{R}^{2}$ value of the final dependent variable is greater than 0.10 , the model is deemed to have appropriate explanatory power [68]. In this model, the attitudes, subjective norms, and perceived 
behavioral control explained $43.7 \%$ of the variance in the behavioral intention of local residents to support additional designation. Overall, the values of the model were higher than the criterion value.

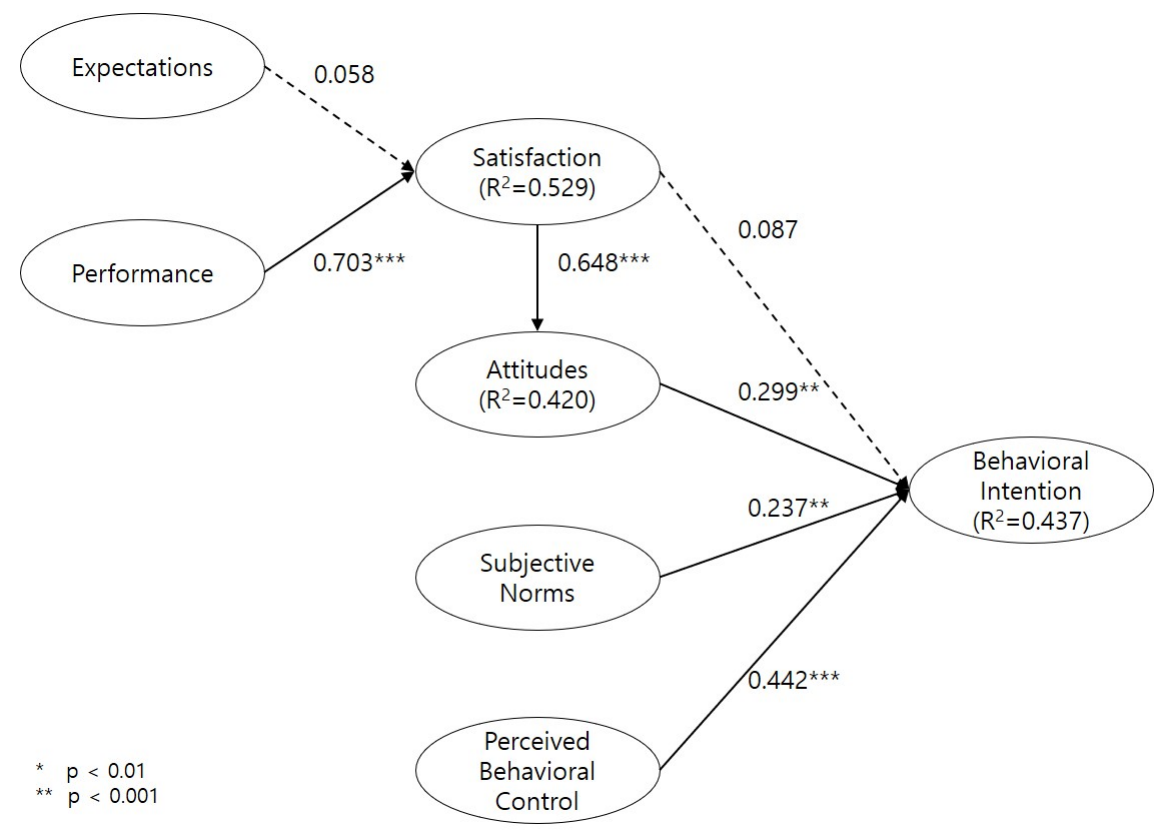

Figure 2. Results of path analysis (standardized regression value).

\section{Discussion and Implications}

This study sought to provide a better understanding of the factors that affect residents' support for the establishment or expansion of PAs. In order to build a more accurate model, the constructs of TPB were supplemented with constructs from EDM to explain how positive or negative attitudes towards PAs are formed. Although there is a myriad of studies on residents' attitudes toward conservation and PAs, very few studies empirically examine how these attitudes are created and whether there are other factors that lead to the actual behavior to support PAs. This study theorized that residents' expectations and the actual experience (perceived performance) with PAs will significantly affect their satisfaction with PAs and their attitudes toward further expansion.

The results suggest, however, that only the perceived performance of PAs is a suitable predictor of satisfaction. Although expectations were found to be useful in explaining citizen satisfaction with government performance [22-28] and visitors' satisfaction from products and services in a PA [20,21], the model employed in this research does confirm this hypothesis. As this was the first study to explore this relationship in the context of residents of PAs, further research is warranted. On the other hand, in accordance with the abovementioned results of the previous studies, the performance was found to be directly linked with satisfaction, which could explain $42 \%$ of the variance in attitudes. The performance refers to economic, environmental, social, and cultural benefits, as well as the provision of information and communication with public stakeholders. The local population in the BDPA is almost entirely composed of farmers that supported the establishment of the original BDPA, encouraged by prospective benefits promoted by KFS. In reality, however, they saw little to no personal and collective benefits. They also perceived that the environmental status of the region has not improved as a result of the establishment of PAs. Moreover, according to the survey, they faced additional zoning regulations and restrictions on their participation, and perceived wildlife conflict with their agricultural activities. Expectancy disconfirmation and social exchange theories that focus on the level of satisfaction and support being directly related with perceived personal and collective costs and benefits can explain this observation. In this context, the results of the study corroborate previous research [8,33-35]. As noted by Durand and Lazos [13], farmers may view conservation 
as important, but in many cases incompatible with farming and inappropriate given their economic dependency on that activity. Faced with limited benefits, communities understand PAs as strategies that involve costs and restrictions, and they believe that they should be compensated in exchange [4].

In addition to the confirmed role of performance in shaping satisfaction, the study also confirms the role of satisfaction in shaping attitudes, in accordance with results of previous studies [42,46-50]. However, contrary to the results of some previous studies that directly linked satisfaction and behavioral intention $[20,21]$, no such relation was statistically significant, showing that attitude was a much better predictor of behavior and that satisfaction was just one component of attitudes. Further research is required to find other significant factors affecting attitudes. Because of the critical role of perceived benefits is shaping pro-environmental and conservation attitudes in the context of PAs confirmed by this study and previous research (e.g., [48-50]) the underlining reasons for positive and negative attitudes require primary attention. Planners and proposers of PAs argue that sustainable land use and ecotourism or nature-based tourism can either substitute or supplement current economic activities, providing enough benefits to ensure residents' commitment to conservation. However, the alternatives more often than not require significant modifications in lifestyles and productive strategies [13]. In the case of BDPA, the majority of surveyed respondents were dedicated to farming and were neither interested in tourism nor had the experience and knowledge about the activity. Instead, they perceived the increased number of visitors as a negative impact of PAs, which negatively affected their perceptions. A similar result was reported by Chung et al. [70]. As residents do not perceive a potential benefit from tourism in PAs, they form negative attitudes towards it, and are not willing nor have confidence to initiate, plan, and develop local tourism initiatives [71].

This lack of understanding about the aspirations of local people and imposition of solutions by the authorities implies ineffective communication and limited public participation of residents in park affairs. If not properly consulted, negotiated, and managed with the communities, the restrictions introduced by PAs are received by the local people as a denial of access to their land and resources, which is the main reason for the lack of trust and conflicts with PA authorities and negative attitudes towards it [72]. This is a very common issue in the designation and management of PAs, which are still dominated by top-down approaches [37]. Every social exchange relationship is based not on power alone but a mixture of both power and trust [73]. Factors that encourage trust in relationships are frequent positive interactions, regular meetings of obligations, maintenance of reciprocity, mutual interdependence, and willingness to listen to and respect all those involved [74].

Nunkoo and Ramkissoon [75] refer to trust in government institutions as "institutional trust", which is very fragile and requires efforts from both sides to be established and maintained. Residents that are more dependent on land and resources, such as farmers, are also more vulnerable to their management, further amplifying the importance of trust and the impacts of distrust [76]. Failures of a trusted stakeholder to deliver on promises decrease the trust, which is the reason for communities tending to mistrust the government [77]. As a consequence of past inadequate government approaches, the residents of BDPA perceive the numerous conservation-related projects that imposed restrictions and brought about little benefits as damaging, which led to the negative perceived performance of the current PAs and negative attitudes toward the additional designation.

In addition to the role of attitudes, the findings of the study also confirm the importance of subjective norm and behavioral control, which is in line with findings of previous studies [43,47-51]. A person's perception of what others think of a particular behavior plays a significant role in explaining their behavioral intention. In relatively small communities in a country characterized by a highly hierarchical culture, the points of view of elders and respected members of the society are greatly valued. Past negative experiences, unkept promises, and restrictions were carefully noted and remembered by the local people, who begin to distrust public authorities and influence opinions of their peers and relatives. In this context, the role of social capital is particularly important in disseminating and promoting a particular view of PAs. Indeed, social group membership has been associated with positive attitudes toward PAs [78]. However, it can be argued that the influence of peers may well lead 
to the opposite stance if the opposing stance is the dominant position within the dominant social group. Moreover, besides subjective norms, perceived behavioral control (PBC) played a significant role in shaping residents' intention to support PAs. In the case of BDPA, PBC was measured in terms of the residents' perceived ability to participate in the meetings and debates about PA expansion. That ability, however, might have been hindered by factors such as a perceived absence of the skills, knowledge, or autonomy required to participate [43]. These aspects underlining PBC require further investigation.

The consequence of an unstable relationship and lack of trust in public institutions is the residents fear that PAs will bring additional restrictions to their livelihoods with little benefits [79]. Moreover, in the case of BDPA, the lack of transparency in policy and decision-making, which is typical of top-down management, deepened that sentiment even further. This type of fear, driven by strong negative perceptions rather than reality, cannot be easily overcome by a simple acknowledgment and promises from public institutions. It requires a participative institutional approach based on information sharing, communication, and trust building. Although a complete description of strategies employed to build residents' trust is out of the scope of this study, the authors feel that they should be briefly discussed.

A stakeholder network built on institutional coordination and active outreach programs is one such strategy that brings stakeholders together, building the residents' capacity to handle management at equal footing with the government through institutionalized arrangements, partnerships, and open dialogues on critical issues [80]. Other strategies include inclusion of local leaders and representatives in park management [81], building trust by taking small steps through small-scale projects of mutual interests that have a high chance to deliver on their promises [12], implementing approaches that fit the local circumstances without imposed "solutions", building policy foundations with the community, providing instances for participation [82], supporting communities of practice [83], and ensuring that residents receive tangible benefits from PAs that outweigh the perceived costs and address the actual needs identified by residents and not the institutions.

Although all the above-mentioned strategies directly or indirectly address building knowledge about PAs' objectives and understanding of the concept among residents, which is an important aspect that affects residents' perception of PA performance and their attitudes toward PAs [5,35], strategies that deliberately target this area are highly advisable. Concerning the importance of subjective norms in shaping behavioral intention, Cetas and Yasue [84] suggest instruments that work through existing institutions or social networks that emphasize the connection between people and the environment. However, only the participative institutional approach to PA management and potential PA designations can generate positive attitudes among influential individuals, who can further disseminate the attitudes to residents through social networks.

\section{Limitations and Future Research}

The principal limitation of the research is a relatively low sample size of 102, which makes roughly $10 \%$ of the total households in each of the 15 villages. The limitation comes from the fact that researchers had to seek local leaders' permission to carry out the survey, which effectively limited the sample size. Although both models used in the research were confirmed in previous research, this study found that the expectations do not explain citizen satisfaction, which contradicts the results of a number of studies. It is possible that this result was affected by the low sample size. However, because those studies were carried out in a context different from PA and, in this study, the expectations and performance were measured at the same time after PA designation, further research is warranted. Future studies should increase the sample size according to the official population dataset. More useful implications could be drawn if objective measurements of expectations and performance are carried out in a similar policy setting in the future. Further research is also required on effective ways to provide the benefits to increase residents' awareness in the PA context. Finally, it should be highlighted that the study was carried out in a specific context of one region in the Republic of Korea; hence the findings might not be generalizable to PAs in different regions and countries. 
Author Contributions: Conceptualization, S.P. and S.-i.K.; methodology, S.P. and S.-i.K.; software, S.P.; validation, S.P., S.Z., and Y.J.; formal analysis, S.P. and Y.J.; investigation, S.P. and S.Z.; resources, S.P. and S.K.; writing-original draft preparation, S.Z.; writing—review and editing, S.Z., S.P., and Y.J.; supervision, S.-i.K. All authors have read and agreed to the published version of the manuscript.

Funding: This research received no external funding

Conflicts of Interest: The authors declare no conflict of interest.

\section{Appendix A}

Table A1. Measurement items.

\begin{tabular}{|c|c|c|c|c|}
\hline $\begin{array}{c}\text { Latent } \\
\text { Variable }\end{array}$ & Category & Variable & Survey Question & Reference \\
\hline \multirow{4}{*}{ Expectations } & General & expect1 & $\begin{array}{l}\text { Before the designation, I expected that the } \\
\text { protected areas would bring rewards or benefits. }\end{array}$ & \multirow{8}{*}[57,58]{} \\
\hline & Economic & expect2 & $\begin{array}{l}\text { Before the designation, I expected that the } \\
\text { protected areas would bring more economic } \\
\text { benefits (resident support projects, income from } \\
\text { tourism, etc.). }\end{array}$ & \\
\hline & Cultural & expect3 & $\begin{array}{l}\text { Before the designation, I expected that the } \\
\text { protected areas would bring more senior centers, } \\
\text { cultural centers, accommodations, and restaurants. }\end{array}$ & \\
\hline & Environmental & expect 4 & $\begin{array}{l}\text { Before the designation, I expected that the } \\
\text { protected areas would improve the } \\
\text { natural environment. }\end{array}$ & \\
\hline \multirow{4}{*}{ Performance } & General & perform 1 & The protected area brought rewards and benefits. & \\
\hline & Economic & perform 2 & $\begin{array}{c}\text { The protected areas brought more economic } \\
\text { benefits (resident support projects, income from } \\
\text { tourism, etc.). }\end{array}$ & \\
\hline & Cultural & perform3 & $\begin{array}{l}\text { The protected areas brought more senior centers, } \\
\text { cultural centers, accommodations, and restaurants. }\end{array}$ & \\
\hline & Environmental & perform 4 & $\begin{array}{l}\text { The protected areas improved the } \\
\text { natural environment. }\end{array}$ & \\
\hline \multirow{7}{*}{ Satisfaction } & General & satisfy1 & Overall, I am satisfied with the designation. & \multirow{7}{*}[32,58,59,85]{} \\
\hline & economic & satisfy2 & $\begin{array}{l}\text { I am satisfied with the economic benefits } \\
\text { after designation. }\end{array}$ & \\
\hline & Cultural & satisfy3 & $\begin{array}{l}\text { I am satisfied with the cultural benefits after } \\
\text { designation such as senior centers, cultural centers, } \\
\text { accommodations, and restaurants. }\end{array}$ & \\
\hline & Environmental & satisfy4 & $\begin{array}{l}\text { I am satisfied with the environmental benefits } \\
\text { after designation. }\end{array}$ & \\
\hline & $\begin{array}{l}\text { Expectancy } \\
\text { confirmation }\end{array}$ & satisfy5 & $\begin{array}{l}\text { The performance of the protected areas meets my } \\
\text { expectations before designation. }\end{array}$ & \\
\hline & $\begin{array}{l}\text { Information } \\
\text { satisfaction }\end{array}$ & satisfy6 & $\begin{array}{c}\text { There was enough information and explanation } \\
\text { about the designation process. }\end{array}$ & \\
\hline & Familiarity & satisfy7 & I am aware of the protected areas. & \\
\hline
\end{tabular}


Table A1. Cont.

\begin{tabular}{|c|c|c|c|c|}
\hline Latent Variable & Category & Variable & Survey Question & Reference \\
\hline \multirow{3}{*}{ Attitudes } & Behavioral belief & attitude1 & $\begin{array}{l}\text { The additional designation of protected areas is } \\
\text { good for the town. }\end{array}$ & \multirow{10}{*}{ [42] } \\
\hline & Assessment & attitude2 & $\begin{array}{l}\text { The benefits will increase if additional protected } \\
\text { areas are designated. }\end{array}$ & \\
\hline & & attitude3 & $\begin{array}{l}\text { I am in favor of the expansion of BDMS } \\
\text { protected areas. }\end{array}$ & \\
\hline \multirow{3}{*}{ Subjective norms } & Normative belief & norm1 & $\begin{array}{l}\text { My family, friends or neighbor think that I agree } \\
\text { with the expansion of protected areas. }\end{array}$ & \\
\hline & $\begin{array}{l}\text { Motivation to } \\
\text { comply }\end{array}$ & norm2 & $\begin{array}{l}\text { I will follow the opinion of my family, friends, or } \\
\text { neighbors when in favor or against the expansion } \\
\text { of protected areas }\end{array}$ & \\
\hline & Normative belief & norm3 & $\begin{array}{l}\text { My family, friends, or neighbors agree with the } \\
\text { expansion of protected areas. }\end{array}$ & \\
\hline \multirow{3}{*}{$\begin{array}{c}\text { Perceived } \\
\text { behavior control }\end{array}$} & Control beliefs & pbc1 & $\begin{array}{l}\text { I can participate in public hearing or briefing } \\
\text { sessions for the expansion of protected areas } \\
\text { (additional designation). }\end{array}$ & \\
\hline & Control beliefs & pbc2 & $\begin{array}{c}\text { I can participate in the process of designation } \\
\text { whenever I want. }\end{array}$ & \\
\hline & $\begin{array}{l}\text { Perceived power of } \\
\text { the control factor }\end{array}$ & pbc3 & $\begin{array}{l}\text { I will actively follow the designation if I can } \\
\text { participate in the process (public hearing } \\
\text { or briefing). }\end{array}$ & \\
\hline \multicolumn{3}{|c|}{ Behavioral intention } & $\begin{array}{l}\text { I will support the expansion of protected areas } \\
\text { (additional designation). }\end{array}$ & \\
\hline
\end{tabular}

\section{References}

1. Walpole, M.J.; Goodwin, H.J. Local attitudes towards conservation and tourism around Komodo National Park, Indonesia. Environ. Conserv. 2001, 28, 160-166. [CrossRef]

2. Cobbinah, P.B.; Black, R.; Thwaites, R. Biodiversity conservation and livelihoods in rural Ghana: Impacts and coping strategies. Environ. Dev. 2015, 15, 79-93. [CrossRef]

3. Stoll-Kleemann, S.; O'Riordan, T. Biosphere reserves in the Anthropocene. In Encyclopedia of Anthropocene; DellaSalla, D., Goldstein, M., Eds.; Elsevier: Amsterdam, The Netherlands, 2018; pp. 347-353.

4. Dewu, S.; Roskaft, E. Community attitudes towards protected areas: Insights from Ghana. Oryx 2018, 52, 489-496. [CrossRef]

5. Dimitrakopoulos, P.G.; Jones, N.; Iosifides, T.; Florokapi, I.; Lasda, O.; Paliouras, F.; Evangelinos, K.I. Local attitudes on protected areas: Evidence from three Natura 2000 wetland sites in Greece. J. Environ. Manage. 2010, 91, 1847-1854. [CrossRef] [PubMed]

6. Gerhardinger, L.C.; Godoy, E.A.S.; Jones, P.J.S. Local ecological knowledge and the management of marine protected areas in Brazil. Ocean Coast. Manage. 2009, 52, 154-165. [CrossRef]

7. Dinham, A. Empowered or over-empowered? The real experience of local participation in UK's new deals for communities. Community Dev. 2005, 40, 301-312. [CrossRef]

8. Walde, J.F.; Huy, D.T.; Tappeiner, U.; Tappeiner, G. A protected area between subsistence and development. Int. J. Commons. 2019, 13, 175-204. [CrossRef]

9. Stoll-Kleemann, S.; Welp, M. Participatory and integrated management of biosphere reserves-Lessons from case studies and a global survey. Gaia 2008, 17, 161-168. [CrossRef]

10. Cuong, C.V.; Dart, P.; Hockings, M. Biosphere reserves: Attributes for success. J. Environ. Manage. 2017, 188, 9-17. [CrossRef]

11. Stoll-Kleemann, S.; O'Riordan, T. The challenges of the Anthropocene for biosphere reserves. Parks 2017, 23, 89-100. [CrossRef]

12. Kaus, A. Environmental Perceptions and Social-Relations in the Mapimi Biosphere Reserve. Conserv. Biol. 1993, 7, 398-406. [CrossRef] 
13. Durand, L.; Lazos, E. The local perception of tropical deforestation and its relation to conservation policies in Los Tuxtlas biosphere reserve, Mexico. Hum. Ecol. 2008, 36, 383-394. [CrossRef]

14. Bragagnolo, C.; Malhado, A.C.M.; Jepson, P.; Ladle, R.J. Modelling Local Attitudes to Protected Areas in Developing Countries. Conserv. Soc. 2016, 14, 163-182. [CrossRef]

15. Yoon, Y.; Uysal, M. An examination of the effects of motivation and satisfaction on destination loyalty: A structural model. Tourism. Manage. 2005, 26, 45-56. [CrossRef]

16. Oliver, R.L. Effect of Expectation and Disconfirmation on Postexposure Product Evaluations-Alternative Interpretation. J. Appl. Psychol. 1977, 62, 480-486. [CrossRef]

17. Oliver, R.L. A Cognitive Model of the Antecedents and Consequences of Satisfaction Decisions. J. Mark. Res. 1980, 17, 460-469. [CrossRef]

18. Mok, J.Y. Proposed non-linear relation between satisfaction with government performance and co-production: An initial empirical test. Public Manag. Rev. 2019. [CrossRef]

19. Curtice, J.; Heath, O. Does Choice Deliver? Public Satisfaction with the Health Service. Polit. Stud. 2012, 60, 484-503. [CrossRef]

20. Lopez-Mosquera, N.; Sanchez, M. Cognitive and affective determinants of satisfaction, willingness to pay, and loyalty in suburban parks. Urban For. Urban Gree. 2014, 13, 375-384. [CrossRef]

21. Okello, M.M.; Yerian, S. Tourist satisfaction in relation to attractions and implications for conservation in the protected areas of the Northern Circuit, Tanzania. J. Sustain. Tour. 2009, 17, 605-625. [CrossRef]

22. James, O. Evaluating the Expectations Disconfirmation and Expectations Anchoring Approaches to Citizen Satisfaction with Local Public Services. J. Public Adm. Res. Theor. 2009, 19, 107-123. [CrossRef]

23. Morgeson, F.V. Expectations, Disconfirmation, and Citizen Satisfaction with the US Federal Government: Testing and Expanding the Model. J. Public Adm. Res. Theor. 2013, 23, 289-305. [CrossRef]

24. Petrovsky, N.; Mok, J.Y.; Leon-Cazares, F. Citizen Expectations and Satisfaction in a Young Democracy: A Test of the Expectancy-Disconfirmation Model. Public Adm. Rev. 2017, 77, 395-407. [CrossRef]

25. Poister, T.H.; Thomas, J.C. The Effect of Expectations and Expectancy Confirmation/Disconfirmation on Motorists' Satisfaction with State Highways. J. Public Adm. Res. Theor. 2011, 21, 601-617. [CrossRef]

26. Vilke, J.B.; Vilkas, M. Discussing municipal performance alternatives: Public perceptions of municipal services delivery in Lithuania. Int. J. Public Sect. Ma. 2018, 31, 525-542. [CrossRef]

27. Van Ryzin, G.G. Expectations, performance, and citizen satisfaction with urban services. J. Policy Anal. Manag. 2004, 23, 433-448. [CrossRef]

28. Van Ryzin, G.G. Testing the expectancy disconfirmation model of citizen satisfaction with local government. J. Public Adm. Res. Theor. 2006, 16, 599-611. [CrossRef]

29. Arambewela, R.; Hall, J. An empirical model of international student satisfaction. Asia Pac. J. Mar. Logist. 2009, 21, 555-569. [CrossRef]

30. Au, A.K.M.; Tse, A.C.B. Expectancy disconfirmation Effects of deviation from expected delay duration on service evaluation in the airline industry. Asia Pac. J. Market. Lo. 2019, 31, 291-300. [CrossRef]

31. Kaski, T.A.; Hautamaki, P.; Pullins, E.B.; Kock, H. Buyer versus salesperson expectations for an initial B2B sales meeting. J. Bus. Ind. Mark. 2017, 32, 47-57. [CrossRef]

32. Chen, C. Investigating structural relationships between service quality, perceived value, satisfaction, and behavioral intentions for air passengers: Evidence from Taiwan. Transport. Res. A 2008, 42, 709-717. [CrossRef]

33. Cardozo, M. Economic displacement and local attitude towards protected area establishment in the Peruvian Amazon. Geoforum 2011, 42, 603-614. [CrossRef]

34. Pullin, A.S.; Bangpan, M.; Dalrymple, S.; Dickson, K.; Haddaway, N.R.; Healey, J.R.; Oliver, S. Human well-being impacts of terrestrial protected areas. Environ. Evid. 2013, 2, 19. [CrossRef]

35. Scanlon, L.J.; Kull, C.A. Untangling the links between wildlife benefits and community-based conservation at Torra Conservancy, Namibia. Dev. South Afr. 2009, 26, 75-93. [CrossRef]

36. Htun, N.Z.; Mizoue, N.; Yoshida, S. Determinants of Local People's Perceptions and Attitudes Toward a Protected Area and Its Management: A Case Study From Popa Mountain Park, Central Myanmar. Soc. Natur. Resour. 2012, 25, 743-758. [CrossRef]

37. Xu, J.Y.; Chen, L.D.; Lu, Y.H.; Fu, B.J. Local people's perceptions as decision support for protected area management in Wolong Biosphere Reserve, China. J. Environ. Manage. 2006, 78, 362-372. [CrossRef] 
38. Hardeman, W.; Johnston, M.; Johnston, D.W.; Bonetti, D.; Wareham, N.J.; Kinmonth, A.L. Application of the theory of planned behaviour in behaviour change interventions: A systematic review. Psychol. Health 2002, 17, 123-158. [CrossRef]

39. Kaiser, F.G.; Hubner, G.; Bogner, F.X. Contrasting the theory of planned behavior with the value-belief-norm model in explaining conservation behavior. J. Appl. Soc. Psychol. 2005, 35, 2150-2170. [CrossRef]

40. Ajzen, I. The Theory of Planned Behavior. Organ. Behav. Hum. Dec. 1991, 50, 179-211. [CrossRef]

41. Beedell, J.D.C.; Rehman, T. Explaining farmers' conservation behaviour: Why do farmers behave the way they do? J. Environ. Manage. 1999, 57, 165-176. [CrossRef]

42. Ajzen, I. Consumer attitudes and behavior. In Handbook of Consumer Psychology; Haugtvedt, C.P., Herr, P.M., Cardes, F.R., Eds.; Lawrence Erlbaum Associates: New York, NY, USA, 2008; pp. 525-548.

43. St John, F.A.V.; Edwards-Jones, G.; Jones, J.P.G. Conservation and human behaviour: Lessons from social psychology. Wildlife Res. 2010, 37, 658-667. [CrossRef]

44. Armitage, C.J.; Conner, M. Efficacy of the theory of planned behaviour: A meta-analytic review. Brit. J. Soc. Psychol. 2001, 40, 471-499. [CrossRef] [PubMed]

45. Godin, G.; Kok, G. The theory of planned behavior: A review of its applications to health-related behaviors. Am. J. Health Promot. 1996, 11, 87-98. [CrossRef] [PubMed]

46. Yuzhanin, S.; Fisher, D. The efficacy of the theory of planned behavior for predicting intentions to choose a travel destination: A review. Tour. Rev. 2016, 71, 135-147. [CrossRef]

47. Brown, T.J.; Ham, S.H.; Hughes, M. Picking up litter: An application of theory-based communication to influence tourist behaviour in protected areas. J. Sustain. Tour. 2010, 18, 879-900. [CrossRef]

48. Infield, M.; Namara, A. Community attitudes and behaviour towards conservation: An assessment of a community conservation programme around Lake Mburo National Park, Uganda. Oryx 2001, 35, 48-60. [CrossRef]

49. Dolisca, F.; McDaniel, J.M.; Shannon, D.A.; Jolly, C.M. A Multilevel Analysis of the Determinants of Forest Conservation Behavior Among Farmers in Haiti. Soc. Natur. Resour. 2009, 22, 433-447. [CrossRef]

50. Ward, C.; Holmes, G.; Stringer, L. Perceived barriers to and drivers of community participation in protected-area governance. Conserv. Biol. 2018, 32, 437-446. [CrossRef]

51. Castilho, L.C.; De Vleeschouwer, K.M.; Milner-Gulland, E.J.; Schiavetti, A. Attitudes and Behaviors of Rural Residents Toward Different Motivations for Hunting and Deforestation in Protected Areas of the Northeastern Atlantic Forest, Brazil. Trop. Conserv. Sci. 2018, 11. [CrossRef]

52. Yoon, S.M. Understanding behavioral intention and support of local residents for tourism event. Korea Acad Soc. Hotel Admin 2015, 24, 127-145.

53. Olson, J.C.; Dover, P.A. Disconfirmation of consumer expectations through product trial. J. Appl. Psychol. 1979, 64, 179-189. [CrossRef]

54. Yoon, Y.; Jang, Y. A Study Moderate Effects of Environmental Education on the Relationships among Experience Expectation, Visit Performance, and Support of Sustainable Tourism. TMRO 2012, 16, 253-270.

55. Lee, J.H. Analyzing local opposition to biosphere reserve creation through semantic network analysis: The case of Baekdu mountain range, Korea. Land Use Policy 2019, 82, 61-69. [CrossRef]

56. Korea Forest Service. Designating Baekdudaegan Ridge as a UNESCO's Biosphere Zone in Korea; Korea Forest Service: Daejeon, Korea, 2005.

57. Lee, S.Y. Factors that Influence the Support of the Baekdu Daegan Moutatin Ssytem as a World Heritage Site: A Survey on Local Community from Namwon, Sangju and Inje. Master's Thesis, Seoul National University, Seoul, Korea, 2015.

58. Tse, D.K.; Wilton, P.C. Models of Consumer Satisfaction Formation-An Extension. J. Mark. Res. 1988, 25, 204-212. [CrossRef]

59. Ye, J.S.; Chang, G.H. The relative effects of determinants of consumer satisfaction. J. Consum. Stud. 1999, 10, 75-91.

60. Song, J.H.; Ko, K.S. Residents' perceived tourism impacts towards regional tourism development. Korean J. Bus. Admin 2015, 28, 37-51.

61. Ajzen, I. Constructing a Theory of Planned Behavior Questionnaire. 2019. Available online: http://people. umass.edu/ \{\}aizen/pdf/tpb.measurement.pdf (accessed on 29 November 2019).

62. Kim, J.H.; Kim, M.G.; Hong, S.H. Writing Papers Using SEM; Communication Books: Seoul, Korea, 2009. 
63. Ullamn, J.B.; Bentler, P.M. Structural Equation Modeling. In Handbook of Psychology; Schinka, J.A., Velicer, W.F., Eds.; John Wiley \& Sons Inc.: Hoboken, NJ, USA, 2003; pp. 607-634.

64. Korea Forest Service. Baekdu-Daegan Recognition Survey; Gallup Korea: Seoul, Korea, 2013.

65. Hair, J.F.; Anderson, R.E.; Tatham, R.L.; Black, W.C. Multivariate Data Analysis, 5th ed.; Prentice-Hall: Upper Saddle River, NJ, USA, 1998.

66. Jayasinghe-Mudalige, U.K.; Udugama, J.M.; Ikram, S.M. Use of structural equation modeling techniques to overcome the empirical issues associated with quantification of attitudes and perceptions. Sri. Lankan. J. Appl. Stat. 2012, 13, 15-37. [CrossRef]

67. Fornell, C.; Bookstein, F.L. Two structural equation models: LISREL and PLS applied to consumer exit-voice theory. J. Market. Res. 1982, 19, 440-453. [CrossRef]

68. Hong, S.H. The criteria for selecting appropriate fit indices in structural equation modeling and their rationales. Korea J. Clin. Psychol. 2000, 19, 161-177.

69. Falk, R.F.; Miller, N.B. A Primer for Soft Modeling; University of Akron Press: Ohio, OH, USA, 1992.

70. Chung, W.; Choi, J.; Woo, C.W.; Lee, S.; Saindon, C.E. Community relations dealing with a not in my back yard (NIMBY) context An experimental application of situational theory of publics and social exchange theory. Int. J. Confl. Manage. 2016, 27, 424-452. [CrossRef]

71. Park, E.; Phandanouvong, T.; Kim, S. Evaluating participation in community-based tourism: A local perspective in Laos. Curr. Issues Tour. 2018, 21, 128-132. [CrossRef]

72. Stone, M.T. Community-based ecotourism: A collaborative partnerships perspective. J. Ecotour. 2015, 14, 166-184. [CrossRef]

73. Bachmann, R. Trust, power and control in trans-organizational relations. Organ. Stud. 2001, 22, 337-365. [CrossRef]

74. Moscardo, G.; Konovalov, E.; Murphy, L.; McGehee, N.G.; Schurmann, A. Linking tourism to social capital in destination communities. J. Destin. Mark. Manage. 2017, 6, 286-295. [CrossRef]

75. Nunkoo, R.; Ramkissoon, H. Power, Trust, Social Exchange and Community Support. Ann. Tourism. Res. 2012, 39, 997-1023. [CrossRef]

76. Davenport, M.A.; Leahy, J.E.; Anderson, D.H.; Jakes, P.J. Building trust in natural resource management within local communities: A case study of the Midewin National Tallgrass Prairie. Environ. Manage. 2007, 39, 353-368. [CrossRef]

77. Lachapelle, P. A sense of ownership in community development: Understanding the potential for participation in community planning efforts. Community Dev. 2008, 39, 52-59. [CrossRef]

78. Anthony, B. The dual nature of parks: Attitudes of neighbouring communities towards Kruger National Park, South Africa. Environ. Conserv. 2007, 34, 236-245. [CrossRef]

79. McNeill, A.; Clifton, J.; Harvey, E.S. Attitudes to a marine protected area are associated with perceived social impacts. Mar. Policy 2018, 94, 106-118. [CrossRef]

80. Zielinski, S.; Kim, S.I.; Botero, C.M.; Yanes, A. Factors that facilitate and inhibit community-based tourism initiatives in developing countries. Curr. Issues Tour. 2020. [CrossRef]

81. Mayaka, M.; Croy, W.G.; Cox, J.W. Participation as motif in community-based tourism: A practice perspective. J. Sustain. Tour. 2018, 26, 416-432. [CrossRef]

82. Yanes, A.; Zielinski, S.; Cano, M.D.; Kim, S.I. Community-Based Tourism in Developing Countries: A Framework for Policy Evaluation. Sustainability 2019, 11. [CrossRef]

83. Reed, M.G.; Godmaire, H.; Abernethy, P.; Guertin, M.A. Building a community of practice for sustainability: Strengthening learning and collective action of Canadian biosphere reserves through a national partnership. J. Environ. Manage. 2014, 145, 230-239. [CrossRef] [PubMed]

84. Cetas, E.R.; Yasue, M. A systematic review of motivational values and conservation success in and around protected areas. Conserv. Biol. 2017, 31, 203-212. [CrossRef]

85. Westbrook, R.A.; Oliver, R.L. The Dimensionality of Consumption Emotion Patterns and Consumer Satisfaction. J. Consum. Res. 1991, 18, 84-91. [CrossRef]

(C) 2020 by the authors. Licensee MDPI, Basel, Switzerland. This article is an open access article distributed under the terms and conditions of the Creative Commons Attribution (CC BY) license (http://creativecommons.org/licenses/by/4.0/). 